\title{
FIELD EVALUATION OF FIVE WHEAT VARIETES AGAINST INSECT PEST INFESTATION
}

\author{
Dhananjoy Kumar Mahato \\ Ex MS Student \\ Department of Entomology \\ Sher-e-Bangla Agricultural \\ University Dhaka -1207, \\ Bangladesh
}

\author{
Md. Mizanur Rahman \\ Professor \\ Department of Entomology \\ Sher-e-Bangla Agricultural \\ University \\ Dhaka -1207, Bangladesh
}

\author{
Sadhan Kumer Guha Magumder \\ Upazilla Agriculture Officer \\ Department of Agricultural \\ Extension \\ Khamarbari, Dhaka-1215, \\ Bangladesh
}

\author{
Kazi Md. Abu Sayeed \\ Sub Divisional Officer \\ Arboriculture PWD sub Division \\ Bangladesh National Parliament \\ Sere Bangla Nagar, Dhaka, Bangladesh
}

\author{
Md. Abu Zafur Al Munsur \\ $\mathrm{PhD}$ Fellow \\ Department of Agronomy \\ Sher-e-Bangla Agricultural University \\ Dhaka -1207, Bangladesh
}

\begin{abstract}
The experiment was conducted to evaluate the infestation status of insect pest on different wheat variety. Five wheat variety (BARI GOM -24, BARI GOM-25, BARI GOM-27, BARI GOM-28and BARI GOM-29) were used as a test crop to conduct the study. The experiment was laid out in Randomized Complete Block Design with three replications. Total 5 insect pests were found from this experiment among wheat aphid and wireworm as major and leaf hopper, grass hopper and cereal leaf beetle as minor insect of wheat. The highest insect pest was found in grain filling stage and lowest was found in panicle initiation stage. In grain filling stage, the lowest number of aphid (6.26) was recorded from BARI GOM-29 and the highest number of wheat aphid (9.11) was found in BARI GOM-24. Effect of different varieties of plant height, filled grain, unfilled grain, weight of $\mathbf{1 0 0 0}$ grain and yield showed significant. The highest yield $\left(3.56\right.$ tha $\left.^{-1}\right)$ was recorded in BARI GOM-29 and the lowest yield 2.29 tha $^{-1}$ was recorded in BARI GOM-25. The highest percentage of infested spike hill $^{-1}$ was recorded in BARI GOM-27 and lowest was found in BARI GOM-29. The lowest yield loss $(31.53 \%)$ was recorded in BARI GOM-29. This is might be due to physical resistance of the varieties. BARI GOM-29 recommended to wheat growers as it is found the most resistant/tolerant wheat cultivar against wheat insect pest with maximum grain yield as compared to other cultivars.
\end{abstract}

Keywords-Field evaluation, Wheat, Variety, Insect pest, Infestation

\section{INTRODUCTION}

Wheat (Triticum aestivum L.) is one of the cereal food crops ranked third worldwide after maize and rice [1]. The largest area of wheat cultivation in the warmer climates exists in the South-East Asia including Bangladesh [2]. In Bangladesh, wheat is the second most important cereal crop. It contributes to the national economy by reducing the volume of import of cereals for fulfilling the food requirements of the country [3]. Wheat supplies mainly carbohydrate $(69.60 \%)$ and reasonable amount of protein $(12 \%)$ where fat $(1.72 \%)$ and mineral elements $(16.20 \%)$ [4]. The total area under wheat was 4.3 lac ha while the total production was 13 lac ton in 2015. To meet the local demand Bangladesh imports huge quantity of wheat from abroad every year. The wheat yield in this country is low $\left(2.16 \mathrm{t} \mathrm{ha}^{-1}\right)$. There are several reasons that can explain the yield variation, which cover both biotic and abiotic factors. Among the biotic factors, unavailability of high yielding varieties [5], incidence of diseases and pests [6] and abiotic factors such as high temperature [7], moisture stress [8] and nutrient deficiency [9-10] are responsible for lower productivity of wheat in the tropics and sub-tropics. Insects can be major threats to wheat producers by direct feeding oras vectors or carriers of disease. In our country, the major wheat insect pests are Aphids, Hessian fly, Cinch Bug, Cutworms, Grasshoppers, Cereal Leaf Beetle, Stink Bug and True Armyworm etc. Beneficial arthropods and some insects are 


\section{International Journal of Engineering Applied Sciences and Technology, 2021 \\ Vol. 5, Issue 9, ISSN No. 2455-2143, Pages 44-49 \\ Published Online January 2021 in IJEAST (http://www.ijeast.com)}

work as natural enemies in wheat held. Parasitoid wasps and spider were more tolerant and active to prey [11]. Plant resistance is defined as the genetically inherited traits in a plant of a population, or a race or variety of a certain species; resulting in less damage than in other (susceptible) individuals which is lack these genetic characteristics. In this way, plant resistance conditioned by the presence of certain genes that express the presence or absence of certain chemical or morphological traits that interfere with the ability of an herbivore to utilize a plant, and the plant to tolerate the attack [12-13]. For better production of wheat proper variety selection is very important. Because now a day's different high variety used have a significant effect on yield and yield contributing characters of wheat. Under optimum sown condition, differences among the genotypes were found to be significant in respect of grain yield. Ground cover at 4-5 leaf stage, days to ant thesis, maturity and flag leaf emergence, plant height, grain filling duration and 1000-grain weight, and insignificant for biomass at final harvest, ground cover at anthesis chlorophyll content of the flag leaf [14]. Therefore, by enhancing local production it is possible to save huge foreign currency of Bangladesh. Development of resistant variety, easy and adaptable agronomic practices and per hectare yield increment is the factors to be considered for expansion of wheat. Considering the above facts, the present research word laid out to know the infestation status of insect and pests on different wheat varieties and to evaluate the varietal performance.

\section{MATERIALS AND METHODS}

The experiment was conducted at the central farm of Sher-eBangla Agricultural University $\left(23^{\circ} 74^{\prime} \mathrm{N}\right.$ latitude and $90^{\circ}$ $35^{\prime}$ E longitude), Dhaka. Bangladesh. Five wheat variety (BARI GOM -24, BARI GOM-25, BARI GOM-27, BARI GOM-28and BARI GOM-29) were used as a test crop to conduct the study. The experiment was laid out in Randomized Complete Block Design with three replications. Seeds have been collected from Bangladesh Agriculture Research Institute (BARI). Each experimental unit plot size of $3.0 \mathrm{~m} \times 2.0 \mathrm{~m}$ has had received homogenous agronomic practices. Seeds were sown continuously maintained distance $20 \mathrm{~cm}$ line to line and $5 \mathrm{~cm}$ plant to plant. Heavy irrigation was done at 30,45 and 60 days after sowing (DAS) respectively followed by weeding.

Petridishes fine camel hair brush, sweep net, aspirator were used for sample collection. Aspirator was used for collecting small insects. Hand magnifying glass, insect collection box and bottles with ethanol were used for identification. Stereoscopic microscope fined with camera was used for taking exclusive photograph. Incidence of major insect pests of wheat was recorded for the entire cropping season and as a major pest aphid, wireworm, and grass hopper and cereal leaf beetle as minor insect were observed. Data were taken from selected plant at tillering, panicle initiation and grain filling stages to identify the intensity of infestation by the major insect pests of wheat.

Data were collected on number of insect and pests plot $^{-1}$, number of healthy and infested tiller plot $^{-1}$, plant height, number of spike hill ${ }^{-1}$, number of filled and unfilled grains spike $^{-1}$, weight of 1000 -grain $(\mathrm{g})$ and yield $\left(\mathrm{t} \mathrm{ha}^{-1}\right)$. The mean values of all the characters were calculated and analyses of variance were performed by the $\mathrm{F}$ (variance ratio) test. The significance of the differences among the mean values of treatment in respect of different parameters was estimated by the Duncan's Multiple Range Test DMRT) at 5\% level of probability [15].

\section{EXPERIMENT AND RESULT}

\section{Insect Pest Incidence}

\subsection{Tillering stage}

Statistically significant variation was found at tillering stage for wheat aphid, wireworm as major insect pests and leaf hopper, grass hopper and cereal leaf beetle as minor insect of wheat (Table 1). In ease of wheat aphid the lowest number of aphid (5.31) was recorded from BARIGOM-29 which was statistically similar with BARIGOM-28 and the highest number of wheat aphid (7.71) was found in BARIGOM-24. In ease of wireworm the lowest number of wireworm (3.54) was recorded from BARI GOM-29 and the highest number of wireworm (4.89) was found in BARIGOM-25. In ease of minor insect the lowest number of leaf hopper (2.73) was recorded from BARIGOM-29 and the highest number of leaf hopper (3.94) was found in BARIGOM-27. The lowest number of grass hopper (3.32) was recorded from BARIGOM-29 and the highest number of grass hopper (4.03) was found in BARIGOM-27. In ease of cereal leaf beetle the lowest number of beetle (2.90) was recorded from BARIGOM-29 and the highest number of beetle (3.53) was found in BARIGOM-24. Results of this work are in accordance with those of [16-21].

Table 1. Varietal performance on number of insect pests of wheat plot $^{-1}$ at tillering stage

\begin{tabular}{|c|c|c|c|c|c|}
\hline \multirow{2}{*}{ Variety } & \multicolumn{2}{|c|}{ Major insect } & \multicolumn{3}{c|}{ Minor insect } \\
\cline { 2 - 6 } & $\begin{array}{c}\text { Wheat } \\
\text { Aphid }\end{array}$ & Wireworm & $\begin{array}{c}\text { Leaf } \\
\text { Hopper }\end{array}$ & Grasshopper & $\begin{array}{c}\text { Cereal } \\
\text { leaf } \\
\text { beetle }\end{array}$ \\
\hline BARIGOM-24 & $7.71 \mathrm{a}$ & $4.51 \mathrm{~b}$ & $3.56 \mathrm{~b}$ & $4.03 \mathrm{a}$ & $3.53 \mathrm{~b}$ \\
\hline BARIGOM-25 & $6.09 \mathrm{~b}$ & $4.89 \mathrm{a}$ & $3.19 \mathrm{c}$ & $3.62 \mathrm{c}$ & $3.30 \mathrm{c}$ \\
\hline BARIGOM-27 & $6.18 \mathrm{~b}$ & $4.03 \mathrm{c}$ & $3.94 \mathrm{a}$ & $4.35 \mathrm{~b}$ & $3.98 \mathrm{a}$ \\
\hline BARIGOM-28 & $5.62 \mathrm{c}$ & $4.4 \mathrm{~b}$ & $3.5 \mathrm{~b}$ & $3.97 \mathrm{~b}$ & $3.56 \mathrm{~b}$ \\
\hline BARIGOM-29 & $5.31 \mathrm{c}$ & $3.54 \mathrm{~d}$ & $2.73 \mathrm{~d}$ & $3.32 \mathrm{~d}$ & $2.9 \mathrm{~d}$ \\
\hline $\begin{array}{l}\text { Level of } \\
\text { Significance }\end{array}$ & $* *$ & $*$ & $* *$ & $*$ & $* *$ \\
\hline
\end{tabular}




\section{International Journal of Engineering Applied Sciences and Technology, 2021 \\ Vol. 5, Issue 9, ISSN No. 2455-2143, Pages 44-49 \\ Published Online January 2021 in IJEAST (http://www.ijeast.com)}

In a column means having similar letter(s) are statistically identical and those having dissimilar letter(s) differ significantly as per 0.05 level of probability

\subsection{Panicle initiation stage}

Statistically significant variation was found at panicle initiation stage for wheat aphid, wireworm as major insect pests and leaf hopper, grass hopper and cereal leaf beetle as minor insect of wheat (Table 2). In ease of wheat aphid the lowest number of aphid (5.82) was recorded from BARIGOM-29 which was statistically similar with BARIGOM-28 and the highest number of wheat aphid (8.47) was found in BARIGOM-24. In ease of wireworm the lowest number of wireworm (3.77) was recorded from BARIGOM-29 and the highest number of wireworm (5.43) was found in BARIGOM-25. In ease of minor insect the lowest number of leaf hopper (2.93) was recorded from BARIGOM-29 and the highest number of leaf hopper (4.28) was found in BARIGOM-27. The lowest number of grass hopper (3.61) was recorded from BARIGOM-29 and the highest number of grass hopper (4.78) was found in BARIGOM-27. In ease of cereal leaf beetle the lowest number of beetle (3.04) was recorded from BARIGOM-29 and the highest number of beetle (4.22) was found in BARIGOM-27. Freier et al. [22] observed that wheat productivity is seriously affected by different wheat insects. Annonymous [23] reported that aphids can cause damage to plants in several ways. They can reduce plant growth directly as they remove plant sap. Some aphids inject a toxin with their saliva that injures the plant host. Russian wheat aphid (Diuraphis noxia) is another important aphid pest of winter wheat.

Table 2. Varietal performance on number of insect pests of wheat plot at panicle initiation stage

\begin{tabular}{|l|c|c|c|c|c|}
\hline \multirow{2}{*}{ Variety } & \multicolumn{2}{|c|}{ Major insect } & \multicolumn{3}{c|}{ Minor insect } \\
\cline { 2 - 6 } & $\begin{array}{c}\text { Wheat } \\
\text { Aphid }\end{array}$ & $\begin{array}{c}\text { Wirew } \\
\text { orm }\end{array}$ & $\begin{array}{c}\text { Leaf } \\
\text { Hopper }\end{array}$ & $\begin{array}{c}\text { Grassho } \\
\text { pper }\end{array}$ & $\begin{array}{c}\text { Cereal } \\
\text { leaf } \\
\text { beetle }\end{array}$ \\
\hline BARIGOM-24 & $8.47 \mathrm{a}$ & $4.91 \mathrm{~b}$ & $3.86 \mathrm{~b}$ & $4.42 \mathrm{~b}$ & $3.87 \mathrm{~b}$ \\
\hline BARIGOM-25 & $6.7 \mathrm{~b}$ & $5.43 \mathrm{a}$ & $3.47 \mathrm{c}$ & $3.98 \mathrm{c}$ & $3.55 \mathrm{c}$ \\
\hline BARIGOM-27 & $6.8 \mathrm{~b}$ & $4.3 \mathrm{c}$ & $4.28 \mathrm{a}$ & $4.78 \mathrm{a}$ & $4.22 \mathrm{a}$ \\
\hline BARIGOM-28 & $6.17 \mathrm{c}$ & $4.78 \mathrm{~b}$ & $3.81 \mathrm{~b}$ & $4.37 \mathrm{~b}$ & $3.86 \mathrm{~b}$ \\
\hline BARIGOM-29 & $5.82 \mathrm{c}$ & $3.77 \mathrm{~d}$ & $2.93 \mathrm{~d}$ & $3.61 \mathrm{~d}$ & $3.04 \mathrm{~d}$ \\
\hline $\begin{array}{l}\text { Level of } \\
\text { Significance }\end{array}$ & $* *$ & $*$ & $* *$ & $*$ & $* *$ \\
\hline
\end{tabular}

In a column means having similar letter(s) are statistically identical and those having dissimilar letter(s) differ significantly as per 0.05 level of probability

\subsection{Grain filling stage}

Statistically significant variation was found at panicle initiation stage for wheat aphid, wireworm as major insect pests and leaf hopper, grass hopper and cereal leaf beetle as minor insect of wheat (Table 3). In ease of wheat aphid the lowest number of aphid (6.26) was recorded from BARIGOM-29 which was statistically similar with BARIGOM-28 and the highest number of wheat aphid
(9.11) was found in BARIGOM-24. Because aphids population have been found greatly disturbed by environment events [24]. Khan et al. [25] found aphid population peak in 4th week of April in Arid zone. These differences might be due to differential environmental conditions and variety of the experimental sites form those observed in the present study.

In ease of wireworm the lowest number of wireworm (4.09) was recorded from BARIGOM-29 and the highest number of wireworm (5.27) was found in BARIGOM-25. In ease of minor insect the lowest number of leaf hopper (3.22) was recorded from BARIGOM-29 and the highest number of leaf hopper (4.20) was found in BARIGOM-27. The lowest number of grass hopper (3.96) was recorded from BARIGOM-29 and the highest number of grass hopper (4.81) was found in BARIGOM-27. In ease of cereal leaf beetle the lowest number of beetle (3.20) was recorded from BARIGOM-29 and the highest number of beetle (4.08) was found in BARIGOM-27.

Table 3. Varietal performance on number of insect pests of wheat plot at grain filling stage

\begin{tabular}{|l|l|l|l|l|l|}
\hline \multirow{2}{*}{ Variety } & \multicolumn{2}{|c|}{ Major insect } & \multicolumn{3}{c|}{ Minor insect } \\
\cline { 2 - 6 } & $\begin{array}{l}\text { Wheat } \\
\text { Aphid }\end{array}$ & Wireworm & $\begin{array}{l}\text { Leaf } \\
\text { Hopper }\end{array}$ & Grasshopper & $\begin{array}{l}\text { Cereal } \\
\text { leaf } \\
\text { beetle }\end{array}$ \\
\hline BARIGOM-24 & $9.11 \mathrm{a}$ & $5.27 \mathrm{a}$ & $4.2 \mathrm{~b}$ & $4.81 \mathrm{~b}$ & $4.08 \mathrm{~b}$ \\
\hline BARIGOM-25 & $7.21 \mathrm{~b}$ & $5.84 \mathrm{~b}$ & $3.77 \mathrm{c}$ & $4.33 \mathrm{c}$ & $3.78 \mathrm{c}$ \\
\hline BARIGOM-27 & $7.31 \mathrm{~b}$ & $4.63 \mathrm{~b}$ & $4.66 \mathrm{a}$ & $5.20 \mathrm{a}$ & $4.53 \mathrm{a}$ \\
\hline BARIGOM-28 & $6.64 \mathrm{c}$ & $5.14 \mathrm{c}$ & $4.14 \mathrm{~b}$ & $4.75 \mathrm{~b}$ & $4.11 \mathrm{~b}$ \\
\hline BARIGOM-29 & $6.26 \mathrm{c}$ & $4.09 \mathrm{~d}$ & $3.22 \mathrm{~d}$ & $3.96 \mathrm{~d}$ & $3.20 \mathrm{~d}$ \\
\hline $\begin{array}{l}\text { Level of } \\
\text { Significance }\end{array}$ & $* *$ & $*$ & $* *$ & $*$ & $* *$ \\
\hline
\end{tabular}

In a column means having similar letter(s) are statistically identical and those having dissimilar letter(s) differ significantly as per 0.05 level of probability

\section{Evaluation of variety}

2.1 Plant height: The analysis of variance for plant height of different varieties of the experiment shows significant at harvest (Table 4). The tallest plant $(99.17 \mathrm{~cm})$ was recorded in BARIGOM-29 which was statistically significant in variety BARIGOM-27and the shortest plant $(96.75 \mathrm{~cm})$ was obtained in BARIGOM-28.

Table 4. Yield contributing characters and yield of different variety of wheat

\begin{tabular}{|c|c|c|c|c|c|c|}
\hline Variety & $\begin{array}{l}\text { Plant } \\
\text { height } \\
(\mathrm{cm}) \pm \\
\text { SE }\end{array}$ & $\begin{array}{l}\text { Number } \\
\text { of Spike } \\
\text { hill }^{-1} \quad \pm \\
\text { SE }\end{array}$ & $\begin{array}{l}\text { Number } \\
\text { of filled } \\
\text { grain } \\
\text { spike }^{-1} \pm \\
\text { SE }\end{array}$ & $\begin{array}{l}\text { Numbe } \\
\mathrm{r} \\
\text { unfilled } \\
\text { grin } \\
\text { spike }^{-1} \\
\pm \mathrm{SE}\end{array}$ & $\begin{array}{l}\text { Weight } \\
\text { of } 1000 \\
\text { grain } \\
\text { (g) } \quad \pm \\
\text { SE }\end{array}$ & $\begin{array}{l}\text { Yield } \\
(\mathrm{t} \text { ha' } \\
\left.{ }^{1}\right) \quad \pm \\
\text { SE }\end{array}$ \\
\hline $\begin{array}{l}\text { BARI } \\
\text { GOM-24 }\end{array}$ & $\begin{array}{l}96.82 \pm \\
0.22 b\end{array}$ & $\begin{array}{l}4.24 \pm 0.0 \\
4 \mathrm{ab}\end{array}$ & $\begin{array}{l}46.10 \pm 0 . \\
42 \mathrm{c}\end{array}$ & $\begin{array}{l}3.16 \pm 0 . \\
07 \mathrm{a}\end{array}$ & $\begin{array}{l}51.33 \pm \\
0.87 \mathrm{ab}\end{array}$ & $\begin{array}{l}2.32 \pm \\
0.02 \mathrm{~d}\end{array}$ \\
\hline $\begin{array}{l}\text { BARI } \\
\text { GOM-25 }\end{array}$ & $\begin{array}{l}97.34 \pm \\
0.15 b\end{array}$ & $\begin{array}{l}4.15 \pm 0.0 \\
2 \mathrm{ab}\end{array}$ & $\begin{array}{l}40.78 \pm 0 . \\
29 \mathrm{~b}\end{array}$ & $\begin{array}{l}3.03 \pm 0 . \\
04 \mathrm{a}\end{array}$ & $\begin{array}{l}53.65 \pm \\
0.34 \mathrm{a}\end{array}$ & $\begin{array}{l}2.29 \pm \\
0.03 d\end{array}$ \\
\hline $\begin{array}{l}\text { BARI } \\
\text { GOM-27 }\end{array}$ & $\begin{array}{l}99.35 \pm \\
0.24 \mathrm{a}\end{array}$ & $\begin{array}{l}4.28 \pm 0.0 \\
8 \mathrm{ab}\end{array}$ & $\begin{array}{l}49.16 \pm 0 . \\
84 a\end{array}$ & $\begin{array}{l}2.99 \pm 0 . \\
09 \mathrm{a}\end{array}$ & $\begin{array}{l}39.47 \pm \\
0.49 \mathrm{~d}\end{array}$ & $\begin{array}{l}2.83 \pm \\
0.04 \mathrm{c}\end{array}$ \\
\hline $\begin{array}{l}\text { BARI } \\
\text { GOM-28 }\end{array}$ & $\begin{array}{l}96.75 \pm \\
0.30 \mathrm{~b}\end{array}$ & $\begin{array}{l}4.30 \pm 0.0 \\
5 \mathrm{~b}\end{array}$ & $\begin{array}{l}46.22 \pm 0 \\
15 \mathrm{~b}\end{array}$ & $\begin{array}{l}3.24 \pm 0 . \\
03 \mathrm{a}\end{array}$ & $\begin{array}{l}46.52 \pm \\
0.33 \mathrm{c}\end{array}$ & $\begin{array}{l}3.11 \pm \\
0.09 \mathrm{~b}\end{array}$ \\
\hline
\end{tabular}




\begin{tabular}{|l|l|l|l|l|l|l|}
\hline BARI & $99.17 \pm$ & $4.48 \pm 0.1$ & $47.56 \pm 0$. & $2.51 \pm 0$. & $52.84 \pm$ & $3.56 \pm$ \\
GOM-29 & $0.01 \mathrm{a}$ & $4 \mathrm{a}$ & $19 \mathrm{~b}$ & $24 \mathrm{~b}$ & $0.81 \mathrm{ab}$ & $0.02 \mathrm{a}$ \\
\hline $\begin{array}{l}\text { Level of } \\
\text { Significa } \\
\text { nce }\end{array}$ & $* *$ & NS & $* *$ & $*$ & $* *$ & $* *$ \\
\hline
\end{tabular}

In a column means having similar letter(s) are statistically identical and those having dissimilar letter(s) differ significantly as per 0.05 level of probability

2.2 No. of Spike hill-1: The analysis of variance for number of spike hill ${ }^{-1}$ of different varieties shows non significant relationship at harvest (Table 4). The highest number of spike hill-1 (4.48) was recorded in BARIGOM-29 which was statistically significant in variety BARIGOM-24, BARIGOM-25 and BARIGOM-27 and the lowest number of spike hill ${ }^{-1}$ (4.30) was obtained in BARIGOM-28. Similar trends were observed by Jan et al., [26] and Irfan et al., [27] who stated that different varieties respond differently due to difference in their genetic makeup.

2.3 No. of filled grain spike ${ }^{-1}$ : The analysis of variance for number of filled grain spike ${ }^{-1}$ of different varieties of the experiment shows significant at harvest (Table 4). The highest number of filled grain hill $^{-1}$ (49.16) was recorded in BARIGOM-27 and the lowest number of filled grain hill ${ }^{-1}$ (46.10) was obtained in BARIGOM-24. This variation was found due to genetically variation. Similar results were reported by Akmal et al. [28] and Nadeem [29], who also observed significant differences among the cultivars for no. of grain spike ${ }^{-1}$.

2.4 No. of unfilled grain spike ${ }^{-1}$ : The analysis of variance for number of unfilled grain spike ${ }^{-1}$ of different varieties of the experiment shows significant at harvest (Table 4). The highest number of unfilled grain hill $^{-1}$ (3.24) was recorded in BARIGOM-28 which was statistically similar BARIGOM24, BARIGOM-25 and BARIGOM-27and the lowest number of unfilled grain hill-1 (2.51) was obtained in BARIGOM-29.

2.5 Weight of 1000 grain: The analysis of variance for number of weight of 1000 grain of different varieties of the experiment shows significant at harvest (Table 4). The highest weight of 1000 grain (53.65) was recorded in BARIGOM-25 and the lowest of weight of 1000 grain (39.47) was recorded in BARIGOM-27. As reported by Ali et al., [30] this larger variation in grain weight may be due to diverse genetic make-up of wheat cultivars and their differential response to prevalent environment during grain filling stage.

2.6 Yield $\left(\mathbf{t ~ h a}^{-1}\right)$ : The analysis of variance for yield of different varieties shows significant variation at harvest (Table 4). The highest yield $\left(3.56 \mathrm{t} \mathrm{ha}^{-1}\right)$ was recorded in BARIGOM-29 and the lowest yield (2.29 $\left.\mathrm{t} \mathrm{ha}^{-1}\right)$ was recorded in BARIGOM-25 which was statistically similar in BARIGOM-24.

\section{Insect infestation}

3.1 Number of infested spike hill'-1: The highest number of infested spike hill-1 0.14 was recorded in BARIGOM-28 and the lowest number of infested spike hill ${ }^{-1} 0.08$ was obtained in BARIGOM-25 (Table 5). It was found that the highest percentage of infested spike hill ${ }^{-1} 2.08 \%$ was recorded in BARIGOM-27.

Table 5. Insect infestation effect of different variety of wheat

\begin{tabular}{|l|c|c|c|c|c|c|}
\hline Variety & $\begin{array}{c}\text { No. } \\
\text { of } \\
\text { spik } \\
\text { e } \\
\text { hill }^{-1}\end{array}$ & $\begin{array}{c}\text { No. of } \\
\text { infeste } \\
\text { d spike } \\
\text { hill- }^{-1}\end{array}$ & $\begin{array}{c}\text { Percent } \\
\text { of } \\
\text { infeste } \\
\text { d spike } \\
\text { hill-1 }^{-1}\end{array}$ & $\begin{array}{c}\text { No. of } \\
\text { filled } \\
\text { grain } \\
\text { Spike- } \\
\text { 1 }\end{array}$ & $\begin{array}{c}\text { No. of } \\
\text { infeste } \\
\text { d filled } \\
\text { grain } \\
\text { Spike }^{-1}\end{array}$ & $\begin{array}{c}\text { Percent } \\
\text { of } \\
\text { infested } \\
\text { filled } \\
\text { grain } \\
\text { Spike }^{-1}\end{array}$ \\
\hline $\begin{array}{l}\text { BARI } \\
\text { GOM-24 }\end{array}$ & 4.24 & 0.09 & 1.62 & 46.1 & 2.12 & 3.52 \\
\hline $\begin{array}{l}\text { BARI } \\
\text { GOM-25 }\end{array}$ & 4.15 & 0.08 & 1.32 & 40.78 & 2 & 3.23 \\
\hline $\begin{array}{l}\text { BARI } \\
\text { GOM-27 }\end{array}$ & 4.28 & 0.12 & 2.08 & 49.16 & 2.71 & 4.24 \\
\hline $\begin{array}{l}\text { BARI } \\
\text { GOM-28 }\end{array}$ & 4.3 & 0.14 & 1.92 & 46.22 & 3.16 & 4.16 \\
\hline $\begin{array}{l}\text { BARI } \\
\text { GOM-29 }\end{array}$ & 4.48 & 0.13 & 1.63 & 47.56 & 2.89 & 3.43 \\
\hline
\end{tabular}

3.2 Number of infested filled grain spike ${ }^{-1}$ : The highest number of infested filled grain spike ${ }^{-1} 3.16$ was recorded in BARIGOM-25 and the lowest number of infested filled grain spike $^{-1} 2.00$ was obtained in BARIGOM-24 (Table 5). It was found that the highest percentage of infested spike hill $^{-1} 4.24 \%$ was recorded in BARIGOM-27.

3.3 Yield loss (\%): The highest yield loss (49.56\%) was recorded in BARIGOM-24 and the lowest yield loss $(31.53 \%)$ was recorded in BARIGOM-29 (Table 6). This is might be due to physical resistance of variety. In above experiment result showed that variety BARIGOM-29 was lowest infested by different insect pest and yield this variety was best variety.

Table 6. Insect infestation effect of different variety of wheat

\begin{tabular}{|c|c|c|c|}
\hline Variety & $\begin{array}{l}\text { Yield } \\
\left(\mathrm{t} \mathrm{ha}^{-1}\right)\end{array}$ & $\begin{array}{l}\text { BARI } \\
\text { recommende } \\
\mathrm{d} \text { average } \\
\text { yield }\left(\mathrm{t} \mathrm{ha}^{-1}\right)\end{array}$ & $\begin{array}{l}\text { Yield Loss (\%) } \\
\text { due to pest } \\
\text { \&other reason }\end{array}$ \\
\hline BARI GOM-24 & 2.32 & 4.60 & 49.56 \\
\hline BARI GOM-25 & 2.29 & 4.40 & 47.95 \\
\hline BARI GOM-27 & 2.83 & 4.70 & 39.78 \\
\hline BARI GOM-28 & 3.11 & 4.90 & 36.53 \\
\hline BARI GOM-29 & 3.56 & 5.20 & 31.53 \\
\hline
\end{tabular}




\section{International Journal of Engineering Applied Sciences and Technology, 2021 \\ Vol. 5, Issue 9, ISSN No. 2455-2143, Pages 44-49 \\ Published Online January 2021 in IJEAST (http://www.ijeast.com)}

\section{CONCLUSION}

Conclusively, it is urged that integrated use of varietal resistance and chemical control are effective for managing aphid infestation on wheat crop without any risk of grain toxicity. In above experiment result showed that variety BARIGOM-29 was lowest infested by different insect pest and yield this variety was best variety.

\section{REFERENCE}

[1] A. R. Majumder, "Assessment of yield loss caused by common root rot in wheat a cultivar in Queensland (Bipolaris sorokiniana)". Australian Journal of Agricultural Research, 13(3): 143-151, 1991.

[2] Y. P. Duhin and P. M. Ginkel. "Wheat cultivation in the warmer climatcsexists in the South-Fast Asia including Bangladesh". Indian Journal of Agriculture Science., 58(l): 13 1-135, 1991.

[3] FAO, "Production Year Book". Food and Agricultural of the United Nations Rome, Italy.49: 201-212, 2007.

[4] BARI, "Increase wheat cultivation and decrease irrigation cost (A folder in Bengali)". Wheat Research Centre. Bangladesh Agriculture Research Institute Nashipur. Dinajpur. pp. 12-15, 1997.

[5] B. Rerkasem, R. Netsangtip, S. Lordkaew and C. Cheng, "Grain set failure in boron deficient wheat". In Proc. Twelfth International Plant Nutrition Colloquium, N. J. Barrow (Ed.), pp. 401-404, 1993.

[6] M.A. Hossain, K.M.S. Islam, and A.T.M.A.I. Mondal, "Effect of sowing date on lentil aphid, Aphis craccivora Koch infestation and yield contributing characters of lentil (Lens culinaris Medik)". Journal of Biological Science, 8: 115-117, 2000.

[7] F. C. Orakwue, "Wheat germplasm development for heat and drought tolerance for Nigeria". Proc: Wheat for more tropical environment.UNDP/CIMMYT, 1984.

[8] A. Bingham, "Varietal response in wheat to water supply in the field and male sterility caused by a period of drought in a glasshouse experiment". Annalsof Applied Biology, 57: 599-608, 1966.

[9] B. Rerkasem, S. Lodkaew and S. Jamjod, “Assessment of grain set failure and diagnosis for boron deficiency in wheat". In Proc: Wheat for the Nontraditional Warm Areas. D.A. Saunders (Ed.), pp. 500-504, Mexico D.F.: CIMMYT. 1991.

[10] M. Jahiruddin and M. A. Hossain, "Effect of Boron and sowing date on seed set, yield and protein content of wheat". Bangladesh Agricultural University Mymensingh, Research Progress, 8: 111-117, 1994.

[11] Anonymous, "Annual report". Entomology Division. Bangladesh Agricultural Research Institute. Joydebpur. Gazipur. pp. 63-69, 2015 .
[12] G.G. Kennedy, J.D. Barbour, "Resistance variation in natural and managed systems". In: Fritz RS, Simms EL, eds. Plant resistance to herbivores and pathogens: ecology, evolution, and genetics. Chicago, IL, USA: University of Chicago Press, 13-41, 1992.

[13] A.D. Smith, "Phylogeny of the North American Asidini (Coleoptera: Tenebrionidae) based on morphology". Annual Meeting, Entomological Society of America. San Diego, CA. (submitted poster), 2005.

[14] M. M. Rahman, A. Hossain, M.A. Hakim. M.R. Kabir. and M.M.R. Shah. "Performance of wheat genotypes under optimum and late sowing condition". Indian Journal of Sustainable Crop Production, 4(6): 34-39, 2009.

[15] K. A. Gornez, A. A. Gomez, "Statistical Procedure for Agricultural Research". International Rice Research Institute. John Wiley and Sons.New York, 139-240, 1984.

[16] M.U.Aslam, M.U. Razaq, F.A. Ahmad, M.U. Faheem and W.A. Akhter, "Population of Aphid (Schizaphis graminum R.) on Different Varieties/Lines of Wheat (Triticum aestivum L.)". International Journal of Agriculture and Biology, 6: 974-977, 2006.

[17] H.U. Farid, A. Bakhsh, N. Ahmad, A. Ahmad and A. Farooq, "Spatial relationships of landscape attributes and wheat yield patterns". Journal of Agricultural Science, 5(1): 275, 2013.

[18] A.S. Burio, "Studies on varietal resistance of wheat cultivars to aphids (Aphdidae: Homoptera), Ph. D. thesis, Department of Entomology", University of Agriculture, Tandojam, Sindh Pakistan, pp: 32-37, 1996.

[19] M.A. Zia, G.M. Aheer, M.K. Mumtaz and K.J. Ahmad, "Field screening of 16 advanced lines of wheat for resistance to aphid, (Homoptera: Aphididae)". Pakistan Entomologist, 21: 95-97, 1999.

[20] S. Sattar, I. Khan, S.K. Khalil, A. Khan and A.U.R. Saljoqi, "Impact of plant phenology of various wheat genotypes on aphid population". Sarhad Journal of Agriculture, 17: 617-621, 2001.

[21] G.M. Aheer, M. Munir and A. Ali, "Screening of Wheat Cultivars against Aphids in Ecological Conditions of District Mandi Bahauddin". Journal of Agricultural Research, 44: 55-58, 2006.

[22] B. Frier, H. Triltch, M. Mowes, and E. Moll, "The potential of predators in natural control of aphids in wheat". Bio. Control, 52: 775-788, 2007.

[23] Annonymous. "Pest Management Strategic Plan for Winter Wheat in the Southern Great Plains". Stakeholder workshop 11 August 2010 (completed and submitted 2012), USDA Grazinglands Research Center, El Reno, Oklahoma. pp: 24-29, 2010. 


\section{International Journal of Engineering Applied Sciences and Technology, 2021 \\ Vol. 5, Issue 9, ISSN No. 2455-2143, Pages 44-49 \\ Published Online January 2021 in IJEAST (http://www.ijeast.com)}

[24] S.A. McDonald, S.E. Halbert, S.A. Tolin and B.A. Nault, "Seasonal abundance and diversity of aphids (Homoptera: Aphididae) in a pepper production region in Jamaica". Environment Entomology, 32(3): 499-509, 2003.

[25] A.A. Khan, A.M. Khan, H.M. Tahir, M. Afzal, A. Khaliq, S.Y. Khan and I. Raza, "Effect of wheat cultivars on aphids and their predator populations". African Journal of Biotechnology, 10(80): 1839918402, 2011.

[26] I. Jan, Usman, I.H. Khalil, and T. Jan, "Performance of Recently Released Wheat Cultivars", Asian Journal of Plant Science, 2(8): 627-632, 2003.

[27] M. Irfan, T. Muhammad, M. Amin, and A. Jabbar, "Performance of Yield and Other Agronomic Characters of Four Wheat (Triticum aestivum L.) Genotypes under Natural Heat Stress". Int. J. Bot., 1(2): 124-127, 2005.

[28] M. Akmal, S.M. Shah, and M. Asim, "Yield performance in three commercial wheat varieties due to flag leaf area". Pakistan Journal of Biological Science, 3(12): 2072-2074, 2000.

[29] M. Nadeem, "Growth, radiation use efficiency and yield of some new wheat cultivars under variable nitrogen rates". M.Sc. thesis., Deptt. Agron., Univ. Agri. Faisalabad, 2001.

[30] Y. Ali, B.M. Atta, J. Akhter, P. Monneveux, and Z. Lateef, "Genetic variability, association and diversity studies in wheat (Triticum aestivum L.) germplasm". Pakistan Journal of Botany, 40(5): 2087-2097, 2008. 